\title{
Phrases Containing Adverbial Aspect in Quran Translation Text: A Structural Study
}

\author{
Sudarmini \\ Faculty of Teacher Training and Education \\ Universitas Ahmad Dahlan \\ sudarminiak@gmail.comp
}

\begin{abstract}
Phrase is a lingual unit of clause constructor formed from two or more words occupying a function within a clause. One of the categories functioning in a phrase is an adverb. Adverbs, as closed categories in Indonesian, are rarely studied, especially in the text of translation such as the translation of the Quran. Aspectual adverb 'keselesaian' is an adverbial that expresses actions or deeds (in the predicate function), sudah selesai, belum selesai or sedang dilakukan (perfective aspects or progressive aspect). The problems focused on phrases contained in the translation of the Quran containing language ethic. The purpose of this study was to describe phrase containing aspectual adverbs in the translation of the Quran in structural perspective. This is a qualitative research. The data were collected by SBLC (Simak Bebas Libat Cakap- non-participant conversational observation) and documentation method, continued with writing technique. The data were analyzed using distributional method. Immediate constituent is the basic techniques and the advanced are deletion, substitution, insertion, and reversal tecnique. The research results in two conclusions. (1) Phrase containing aspectual adverbs occupy the function of $P$ as many as 41 phrases in 6 types, function of $S 6$ phrases, function of $K 5$ phrases, function of $O 2$ phrases, and function of Comp. 2 phrases with different variations. (2) Constructing categories of phrase structure: direct verb phrase, indirect Verb phrase, verb phrase in the noun phrase, verb phrase in prepositional phrase (direct and indirect), and Adj. Phrase (Direct adj. phrase and adj. phrase in prepositional phrase).
\end{abstract}

Keywords-adverbs; aspectual adverbs; structure

\section{INTRODUCTION}

Phrase is a potential construction in the formation of larger lingual units, for it functions to fill the clause. Ramlan (2005) explains that phrase is a group of words consisting of two or more words. It means that phrase has two characteristics that consists of two or more words (1) and it functions within a clause (2). Thus, phrase is a significant lingual unit in a clause.

Functioning within a clause, phrase is not predicative (Kridalaksana, 2011). It means that the relation between one unit and another in a phrase is not predicative. The relation can be both tight and loose. Tight, for example in the attributive endocentric phrase, while loose, for example in both coordinative and apositive endocentric phrase.

Phrase construction developed by a variety of categories. Ramlan (2005) mentions kinds of phrases based on the category that form it. It is divided into noun phrase, verb phrase, adjective phrase, numeral phrase, and prepositional phrase. The five phrases are filled by a very diverse category, including adverbs.

Adverbial belongs to closed categories (Chaer, 2015: 48) that quite varied compared to other closed categories. Unlike the open category, adverbs only function to help other categories to make a phrase. Alwi (2014) states that adverbs usually modify verbs, nouns, adjectives, and other adverbs to form a phrase. The idea is in line with Chaer's opinion (2015).

Adverbial aspect is one of other types that is distinguished by Chaer by its meaning. Adverbial aspect is an adverb that states an activity or activities carried out by the verbs occupying P; activities that have not finished, ongoing, or finished (2015). Compared to other adverbs, adverbial aspects have many variations, among them are belum, baru, mulai, sedang, lagi, tengah, masih, sudah, telah, sempat, and pernah.

Phrases containing adverbial aspects are phrases occupied by adverbs that refer to aspects. The adverbs mostly function as predicate of a clause. According to Alwi (2015), most main clause of Indonesian language contains verb phrase as the predicate. It increases the numbers of variation when the verb phrase containing adverbials become the part of other phrase and does not only function as verb. The example is in Quran chapter Al-Mujadilah (58) verse 9: "Cukuplah bagi mereka neraka jahanam yang akan mereka masuki." Here, the neraka jahanam yang akan mereka masuki is noun phrase and functions as the subject of the clause. The clause contains passive verb phrase with adverbial aspect akan.

Phrases that contain adverbial aspects in the Quran Translation Text occupy not only the function of P, but also other functions: S, O, Comp., and Adv. Phrases that occupy several functions are not directly the center of the phrase. There are some in the form of attributes, such as clauses "orang-orang yang telah dilarang (have been forbidden from) mengadakan pembicaraan rahasia". The phrase telah dilarang is the attribute of phrase orang-orang yang telah dilarang as the subject of the clause. Phrase that functions as $\mathrm{S}$ is always a noun phrase. Adverbial in the phrase together with the verbs (verb phrase) become the attribute in nominal phrases which occupy $\mathrm{S}$ in a clause. 
Adverbials have been studied in several researches, both intra-clausal and extra-clausal. Damayanti (2012), Devi (2014), and Mudrikah (2014) have conducted researches on intra-clausal adverbial, of which the data were obtained from novels, series, and opinion rubrics of newspaper. In addition, Tampubolon (2007) has carried out a research on Indonesian adverbials. The aforementioned research all discussed intra-clausal adverbials, particularly the forms, meaning, and functions. Studies in several international journals on adverbials are mostly about extra-clausal adverbials. Among the researchers are Colonna S (2013), Martinnesekali (2012), and Rajaboval (2014).

Markhamah et al $(2014,2015)$ conducted research of which the data were from Quran Translation Text. Both research discussed pronoun. Besides, there is a research that has been published as a textbook entitled Sintaksis 2: Keselarasan Fungsi, Kategori, dan Peran dalam Klausa (Markhamah et al, 2010). As a source of data, Quran translation text is an interesting phenomenon in the use of language, particularly Arabic. One interesting object is the construction of phrases containing adverbial aspects.

One of the data found is in the form of phrase occupying one of clause containing adverb that means aspects.

\section{Translation:}

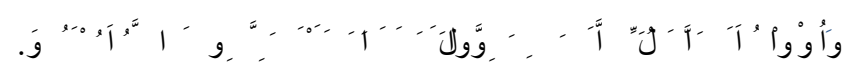

"Mereka berkata: "Mohonkanlah kepada Tuhanmu untuk kami agar Dia menerangkan kepada kami bagaimana hakikat sapi betina itu, karena sesungguhnya sapi itu [masih] samar bagi kami dan Sesungguhnya kami insya Allah akan mendapat petunjuk [untuk memperoleh sapi itu]" ("They said:" Pray to your Lord for us that He explains to us how the nature of the cow, because the cow actually [still] undefined for us and if God wills, we will be guided [to get the cow].")

There are several phrases containing adverbials in the above text. Those are (masih) samar and insya Allah akan mendapat. Both phrases are the predicate of different subordinate clause. Both have different constructions as well. The study on the adverbials is necessary not only to describe the adverbials, but also to describe the functions containing adverbial aspects and categories in the phrase.

Literature review in this paper is divided into several parts: syntactic structure, phrase structure, phrase filler category, adverbial category, and adverbial with aspect meaning. This decomposition is merely to facilitate the description of the theory being used.

\section{Syntactic Structure}

Syntactic is one of the studies in linguistics that belongs to the study of grammar. Sintactic topics includes three cases: the phrase, clause, and sentence. Although some linguists disagree with lingua unit clause, the present research still uses the lingual unit clause to facilitate the analysis.

Physical building of this lingual unit is known as a structure. A clause consists of at least two elements, $\mathrm{S}$ and $\mathrm{P}$ (Ramlan, 2005). It is in accordance with the ideas suggested by Markhamah (2013). Elements of P and S as compulsory element, whereas O, Comp., and Adv are optional or arbitrary. Alwi (2009) explains that the clause in Indonesian language consists of a structure called the basic sentence patterns, ie Noun Phrase+Noun Phrase, Noun Phrase+Verb Phrase, Noun Phrase+Numeral Phrase, and Noun Phrase+Prepositional Phrase.

To functions within a clause, a phrase is given characteristics as a lingual unit, consisting of two or more words (1) and do not go beyond the function (2). That is, the phrase just occupies one function only in the clause. Ramlan (2005) split the phrase by its distribution to endocentric and exocentric phrase. Exocentric phrase is further divided into three: attributive, coordinative, and apositive endocentric. Based on the distribution of the UP said it, there are nominal, verbal, phrases, numeral, and adverbial phrases.

Phrase fillers depend highly on the type of phrase based on distribution and categories of words that become its UP. Noun phrases is the phrase of which the UP is in noun form, as well as the verb phrase with UP in V category; Numeral Phrase is a phrase of which the UP is numeral category; Adjective Phrase UP is adjective category; and Adverb Phrase UP is an adverbs category. The five phrases are endocentric phrase. Meanwhile, the prepositional phrase is a phrase that begins with preposition as a marker and its axis in the form of $\mathrm{N}$ or NP.

\section{Adverb of Aspects}

Kridalaksana (1994) in the book Kelas Kata dalam Bahasa Indonesia, defined adverbial as categories that can accompany an adjective, numeral, or propositions in the syntactic construction. In another book, Kridalaksana explained that adverbial is the word used to describe verbs, adjectives, proposition, or other adverbs, eg, very, much, no, and so on, sorted by extralingual, intralingual and conjunctive adverb (2011).

According to Alwi, et al. (2014) adverbial is distinguished into adverbial that functions in phrases and in clause. In phrases, adverbial is a word that modifies a verb, adjective, or another adverb. For example, Ia sangat mencintai istrinya, the adverbial sangats explain the verb mencintai on adverb phrase sangat mencintai that occupies the function of P (predicate) in clauses with the pattern S P O. Observing it in a clause, the adverb describes certain syntactic functions, not only the function of $\mathrm{P}$. Therefore, a number of adverbs do not only modify verbs, adjectives, and other 
adverbs, but also explain nouns and prepositional phrase. Because pronouns and numeral in the terms of category are very close to noun, adverbials can also explain pronouns and numerals.

Adverbial aspect is adverbial that explains an act or a behavior (in the predicate function) whether it is completed, not finished, or on going (Chaer, 2015). According to Chaer (2015) The adverbials include belum, baru, mulai, sedang, lagi, tengah, masih, sudah, telah, sempat, and pernah. All these adverbs precede a verb or an adjective (which functions as a predicate).

\section{METHODS}

The research belongs to descriptive qualitative study. According to Moleong (2007) Qualitative research was a research that was intended to describe the symptoms experienced by the research subject. It included linguistic research, which explained the phenomenon of adverb categories in phrases that occupying clause in Quran Translation Text.

The data source of this study was Quran Translation Text containing the language aesthetics, which consisted of 109 verses in 47 chapter. The subjects of this study was treated as the data source, while the research object was phrases that contained adverbial aspect in Quran translation text.

The method of collecting the data (Sudaryanto, 2015), or commonly known as data collecting methods, was carried out through observation method. Sudaryanto suggested that data in the form of written language data could be analyzed using observation method. Thus, researchers observed the written text, which was the document in the form of Quran translation text. Advanced technique used was SBLC (Simak Bebas Libat Cakap-nonparticipant Conversational Observation) technique and writing technique.

The data were validated using by triangulation. It (Sutopo, 2006) was one of the methods used in checking the data validity in qualitative research. The research employed three triangulation: source validity, researcher's triangulation, and theoretical triangulation.

The data were analyzed using distributional method. The determining factor in the method was the language in question (Sudaryanto, 2015). Immediate constituent was the basic techniques and the advanced are deletion, substitution, insertion, and reversal technique.

\section{FINDING AND DISCUSSION}

The results of the study presented here (1) the functions of adverbial aspects in a clause and its structures and (2) categories that form the phrase structure containing adverbial aspects.

Clauses containing adverbial aspects are dominated by the function of $\mathrm{P}$, as many as 41 , function of $\mathrm{S} 6$, function of K 5, and function of Comp. and $\mathrm{O} 2$ data of each. The discussion cannot explain all the data,

Phrases that contain adverbial aspect are verb phrase, adjective phrase, and Adjective phrase of Noun phrase. (1) Verb phrase divided into direct verb phrase as much as 36 phrases in Quran Surah (27:70), (2:83), (2: 235), (3: 118), (5:13), 2 (5:41) , 2 (5:101), 4 (6:93), (6:108), (6:151), (10:100), (11:69), (14:25), (17:23), (18:23), (18:24), (22:24), (24:53), (24:63), (34:23), (35:10), 2 (38:26) (43:89), (45:6), (46:17), (46:31), (47:21), (48:11), (2:71). Indirect verb phrase as much as 2 data contained in the Qur'an Surah (3: 118), (7: 161). Verb phrase of Noun phrase as many as 9 data contained in the Quran Surah (2:71), (24:53), (34:23). (5:41), (5:63), 2 (58: 9), (7: 164), (14:24). Verb phrase of the prepositional phrase, direct verb phrase as much as 3 data in Quran Surah (34:23), (58: 9), (5:41) and indirect verb phrase in Quran Surah (46:15), (2:32), (2:40). (2) Adjective phrase as much as 2 data in Quran Surah (27:70), (46:15) and (3) Adjective phrase of Noun phrase in Quran Surah (4:5).

Not all phenomena of the data can be explain in the discussion. The study only discusses two problems: (1) functions of the phrase containing adverbial aspects and (2) categories of the phrase containing adverbial aspects

\section{Function occupied by adverb of aspects in the translation the Qur'an}

The most dominant function is the function of $\mathrm{P}$, as many as 41 data. Theoretically proved that adverbs are categories that accompany the verb to be a phrase that fills the function of $\mathrm{P}$. There is varied construction, namely Type I (Adv. Aspects + V), Type II (Adv. Aspects + Adv. Aspects + V), Type III (Adv . Aspects + RV), type IV (Adv. Aspects + Adj.), type V (Adv.Aspect + passive V), type VI (VP (Adv.A + V) in NP).

The second function containing adverbial aspects that is the function of $\mathrm{S}$, comprising 6 data. Phrases containing the adverb and occupy such function is noun phrases. However, adverbs are in the phrase accompanying verb, which is verb phrase (Adv. Aspects + V) in a Noun Phrase. There are two tendencies in the situation: verb phrase containing adverbials indirectly precedes the verbs and directly precedes the verb.

(1) akan mengerjakan itu (will do it) (QS 18:23)

(2) insya Allah akan mendapat (will receive, God willing) (QS 2:70)

(3) akan menyebut-nyebut (will mention) (QS 2:235)

(4) (masih) samar ([still] undefined) (QS 27:70)

(5) telah kami terangkan (we have explained) (QS 3:318)

(6) orang-orang yang telah diuji hati mereka oleh Allah swt. (persons whom Allah the hearts are tested)(QS 49:3) 
There are five phrases that contain adverb that occupy the function of $\mathrm{K}$, the five phrases are in the form of prepositional phrase with a preposition marker to, from, for and to. In that five data, adverbs of aspect accompany verbs in the prepositional phrase.

(7) kepada orang-orang yang belum sempurna akalnya (to the people who have not have perfect wits) (QS 4:5)

(8) bagi orang-orang yang telah diizinkan-Nya (for those who have allowed by Him) (QS 34:23)

Phrases that occupy the function of $\mathrm{O}$ and Compliment each have two data. Phrases that contain adverb occupying the function of $\mathrm{O}$ such as noun phrases and adverbs in the phrase accompanying verb that is in the noun phrase.

(9) kaum Allah yang akan membinasakan mereka (people whom Allah will destroy them) (Qur'an Surah 7: 164)

In contrast to the phrases that contain adverbs of aspects that occupy the function of Comp., both of the phrase are in the form of noun phrase which there are Verb Phrase in it (Adv. + passive V) and Verb Phrase (adv Aspect + Adv.Aspek $+\mathrm{V})$, both located in the noun phrase.

(10) nikmat-Ku yang telah Aku anugerahkan kepadamu (my facor which I bestowed upon) (QS 2:40)

(11) perkataan-perkataan orang lain yang belum pernah datang kepadamu (the words of others who have never come to you) (QS 5:41)

\section{Constructing category of the phrase structure containing adverbial aspects}

The category most accompanied by adverbial aspect is a verb. It is in the form of verb phrase, adjective phrases, and adjective phrases in the noun phrase. There are several variations of verb phrase: direct verb phrase, indirect verb phrase, verb phrase in the noun phrase, and verb phrase in prepositional phrase.

Direct and indirect verb phrase distinguished by the presence of the adverbs of aspect that attached with verbs, on the right or left of the verb, which is indirectly means there is other word among them, eg pronouns.

(12) (Qur'an Surah 34:23) yang telah difirmankan

$$
\begin{gathered}
\text { S / NP } \\
\text { Pnd. + VP (Adv.A + V) }
\end{gathered}
$$

(13) (Qur'an Surah 58: 9) Neraka jahanam yang akan mereka masuki

$$
\begin{gathered}
\text { S / NP } \\
\text { N N Pnd. VP (Adv.A + Pronom. + VP) }
\end{gathered}
$$
direct

The next data is VP in NP and VP in prepositional phrase. VP in the NP consists of VP that is an attribute of the core of N, whereas VP in prepositional phrase VP which is part of the axis of prepositional phrase in the form of NP.

(14) (Qur'an Surah 24:23) adalah ketaatan yang sudah dikenal

$$
\begin{aligned}
& \mathrm{P}(\text { copula + NP) } \\
& -\mathrm{N}+\text { Pnd. + VP (Adv.A + V) }
\end{aligned}
$$

(15) (Qur'an Surah 4: 5) kepada orang-orang yang belum sempurna akalnya

$$
\mathrm{K} / \text { prepositional phrase/ } \mathrm{F} \text { exo. }
$$

$$
\text { Pnd./Prep axis / NP (N + Pnd. + Adv.S + Adj }+N)
$$

The next adverbial aspect precedes adjectives in adjective phrases and adjective phrases in the NP. Adverbial aspects that accompany the adjective phrase precedes adjective as an attribute, while the adverbs in adjective phrase in NP parsed the same as before.

(16) (Qur'an Surah 46:15) telah dewasa

$$
\begin{aligned}
& \text { P / Adj. P/ endo.atr P } \\
& \text { Atr./Adv.A. UP / adj. }
\end{aligned}
$$

(17) (Qur'an Surah 4: 5) kepada orang-orang yang belum sempurna akalnya

$$
\mathrm{K} / \mathrm{F} \text { prepositional / } \mathrm{F} \text { exo. }
$$

Pnd./Prep axis / NP (N + Pnd. + Adv.S + Adj + N) 


\section{CONCLUSION}

The discussion results in two conclusions. (1) Phrases containing adverbial that occupy the function of $\mathrm{P}$ is 41 phrases in 6 types, of S 6 phrases, of K 5 phrases, of O 2 phrases, and of Complement 2 phrases, with different variations. (2) Constructing categories of phrase structure: direct verb phrase, indirect Verb phrase, verb phrase in the noun phrase, verb phrase in prepositional phrase (direct and indirect), and Adj. Phrase (Direct adj. phrase and adj. phrase in prepositional phrase).

\section{References}

Alwi, H, dkk. (2014). Tata Bahasa Baku Bahasa Indonesia (Cetakan IX). Jakarta: PT Balai Pustaka (Persero). Chaer, A. (2015). Sintaksis Bahasa Indonesia (Pendekatan Proses). Jakarta: Rineka Cipta.

Christina, D. (2008) " Adverbia Verba Bahasa Rusia dan Pengungkapan Maknanya dalam Bahasa Indonesia”. Sosiohumaniora, Vol. 10, No. 1 Maret 2008. Hlm 13-23.

Colonna, S., M. Charolles, L. Sarda, \& J. Pynete. (2013). "Efek pada Pemahaman Preposed versus Postposed Frase Adverbial". Dipublikasi online: Springer Science + Businnes Media New York.

Damayanti, T. (2012). “Adverbia Penanda Modalitas dalam Novel Karya Andrea Hirata: Suatu Kajian Struktur dan Makna”. Skripsi. Universitas Pajajaran Bandung.

Devi, K.A.A. dan Wini Tarmini Karomani. (2014). "Adverbia pada Artikel Opini Kompas dan Implikasinya dalam Pembelajaran”. Jurnal Kata (bahasa, Sastra, dan Pembelajarannya) April 2014. Hlm. 1-8.

Kridalaksana, H. (2011). Kamus Linguistik:Edisi keempat. Jakarta: PT Gramedia.

Markhamah et al, (2010). Sintaksis 2: Keselarasan Fungsi, Kategori, dan Peran dalam Klausa . Surakarta: Muhammadiyah University Press.

Markhamah. (2013). Ragam dan Analisis Kalimat Bahasa Indonesia. Surakarta: Muhammadiyah University Press.

Markhamah, Abdul Ngalim, Muinuddinilah Basri. (2014). "Penggunaan Satuan Lingual Yang Mengandung Pronomina Persona pada Teks Terjemahn Alquran dan Hadis". Laporan Penelitian. Dibiayai ole Dikti melalui skim Hibah Tim Pascasarjana.

Markhamah, AN, MM, Basri, \& M Erlinawati. (2015). "Peran Yang Diisi oleh Satuan Lingual Berponomina Persona Pertama pada Teks Terjemah Al Quran”. Prosiding pada University Research Colloquium. Magister Pengkajian Bahasa. Universitas Muhammadiyah Surakarta. ISSN 2407-9189.

Martinesekali. (2012). "The Emergence of Complex Sentences in a Friend Child's Language from 0;10 to 4;01: Causal Adverbial Clauses and The Concertina Effect". University of Paris Oquest Nanterre La Defense. DOI: $10.1017 /$ S09592695110000615.

Mudrikah, S. (2014) “Adverbia Bahasa Jawa pada “Cerbung Ngonceki Impen” pada Majalah Penyebar Semangat Edisi Maret-Agustus 2014”. Jurnal Bahasa dan Sastra Jawa. Universias Muhammadiyah Purworejo.

Moleong, L J. (2007). Metodologi Penelitian Kualitatif. Bandung: Rosda Karya.

Rajabova, A A. (2014). "Variation of the Word Denoting the Adverbial Modifier of Purpose as to the Position in the Simple Sentences (On the Materials of the English and Azerbaijani Languages)" International Journal of English Linguistics; Vol. 4, No. 3; May 27, 2014. 106-112. ISSN 1923-869X E-ISSN 1923-8703 Published by Canadian Center of Science and Education.

Ramlan, M. (2005). Ilmu Bahasa Indonesia Sintaksis. Yogyakarta: C.V. "Karyono".

Sudaryanto. (2015). Metode dan Aneka Teknik Analisis Bahasa: Pengantar Penelitian Wahana Kebudayaan secara Linguistis. Yogyakarta: Sanata Dharma University Press.

Sutopo, HB. (2006). Metode Penelitian Kualitatif. Surakarta: Universitas Sebelas Maret Press.

Tampubolon, F. (2007).“ Pemberian Pemakaian Adverbia dalam Bahasa Indonesia”. Jurnal Historisme, Edisi No. 23/Tahun XI/Januari 2007. Universitas Sumatera Utara. 